Jurnal Ekonomi dan Perbankan Syariah

Vol. 8. No.2, 0ktober 2020: 41-64, ISSN (cet): 2355-1755 | ISSN (online): 2579-6437

DOI: https://doi.org/10.46899/jeps.v8i2.227

\title{
ANTECEDENTS OF PHILANTHROPIC BEHAVIOR OF PEOPLE LIVING IN JABODETABEK DURING COVID-19 PANDEMIC
}

\author{
Ida Faridatul Hasanah', Donny Setiawan², Nining Nurhasanah ${ }^{3}$
}

${ }^{I}$ SEBI: Email : idafdth@gmail.com

${ }^{2}$ SEBI Lecturer Email : donny.setiawan1976@ gmail.com

${ }^{3}$ SEBI Lecturer Email : nining2010@gmail.com

\begin{abstract}
This study aims to examine the antecedents of the philanthropic behavior in the Jabodetabek community in the era COVID-19 pandemic. This type of research is a descriptive qualitative study consisting of 2 (two) variables used, namely exogenous and endogenous. The population in this study is the Jabodetabek community with 400 samples of respondents. The data analysis method used is the partial least squares structural equation modeling (SEM-PLS) method with the help of SmartPLS 3.0 software. The results of this study indicate that: (1) individual factors on philanthropic behavior in this study do not have a positive and significant effect, (2) organization factors on philanthropic behavior in this study have a positive and significant effect, (3) social factors on philanthropic behavior in this study. This has no positive and significant effect.
\end{abstract}

Keywords: Philanthropic behavior, Philanthropic society, Pandemic, COVID-19

\section{INTRODUCTION}

The world is currently beset by anxiety caused by one of the new types of coronavirus. Since corona virus disease or known as COVID-19 was first discovered in late December 2019 in Wuhan City, China. So the Chinese government made a policy of imposing a lockdown or restriction of entry to Wuhan (Anniss, 2020) COVID-19 can infect the respiratory system, including experiencing flu symptoms and accompanied by high fever, colds, dry cough, sore throat, and excessive headaches if a person is diagnosed positive infected with the virus (Yulianan, 2020). The impact of the rapid spread of viral infections from country to country and has a major impact on the globe, so the World Health Organization (WHO) declared it a global pandemic (WHO, 2020)

Pandemic is the occurrence of one plague that happens in the world and becomes a global outbreak. This pandemic occurs because of one of the new viruses from the coronavirus family. Detected this new type of virus can infect people and transmit it to others in a fast and sustainable way (Murti, 2020). Often the characteristics of viruses that are difficult to properly define or the increasing rate of infection worsen the condition of people who are infected, and humans who have weak body immune will be very easily infected with this new type of coronavirus. (Pramana, 2020) 
It was first recorded that the COVID-19 virus got through in Indonesia on March 2, 2020, at that time as many as 17,514 were confirmed positive until May 17, 2020. A total of 4,129 were declared cured of the virus and a total of 1,148 were declared dead on May 17, 2020. Government's lack of understanding on tackling the COVID-19 virus has caused almost the entire world to become infected with the COVID-19 virus. Many people lack awareness of the importance of maintaining health and hygiene as well as the lack of socialization on the prevention and control of COVID-19 in the community so that the rapid distribution of infection among people and many do not know that he is under monitoring (ODP) or a patient under supervision (PDP) (Maduningtias, 2020).

Maintaining cleanliness is one of the guidelines for the prevention of COVID-19 coronavirus, by diligently washing hands using liquid soap, avoiding not touching 3 areas of the face namely the eyes, nose, and mouth of the three areas is the entrance of the virus into the human body (Alias \& Ismail, 2020) Include not to connect directly between each other or maintain social distancing (social distancing / physical distancing)at least 1 meter with the distance of others (Fathoni, 2020) Maintain respiratory hygiene by doing several things, namely covering the mouth and nose with tissues or with elbows in case of clean and coughing. Then keep wearing a mask if traveling outside, and still comply with health protocols established by the government. If you have a fever, cough, and difficulty breathing immediately take intensive measures to get medical treatment immediately (Coronavirus \& Activities, 2020)

Such a huge impact makes some people have to feel the crisis caused by the COVID-19 pandemic as they emphasize the crisis point of public consumption in Indonesia, the various policy assumptions established during the pandemic, and the various losses experienced. (Rahmadia, Febriyani, Kuala, Islam, \& Kuala, 2020). From home-based workers to workers who choose to close their businesses due to the lack of income during the COVID-19 pandemic (Bagus, 2020)

The government has made some policies to anticipate the impact of COVID-19 that causes anxiety in the community, as well as being the main target caused by the COVID-19 pandemic. The economic crisis experienced by some countries is a concern for the state and several communities. activities are things to increase the optimism of other people amid a pandemic. The government has issued social assistance (Bansos) to people impacted by coronavirus. On the other hand, the people who are considered rich raise awareness by contributing to help the poor by doing fundraising, making donations. Other groups help sew PPE for health workers as well as produce large quantities of masks to distribute to people who still have to work outside.

Giving charity is a habit carried out continuously without being interrupted to become a regular lifestyle. Good habits done early on will have a positive impact on oneself as well as others. By starting from a compulsion, the habit of being trained voluntarily is carried out. Various facilities are given to make it easier for us to do activities in the midst of the COVID-19 pandemic (Nurhidayat, 2020) 
Jurnal Ekonomi dan Perbankan Syariah

Vol. 8. No.2, 0ktober 2020: 41-64, ISSN (cet): 2355-1755 | ISSN (online): 2579-6437

43

From the discussion above that explains the impact of COVID-19 which has become a global pandemic, there has been a crisis in various sectors of the state and causes the global economy to fall, as a result of the people as consumers and production experienced a consumption crisis. The government sees this and encourages people to stay alive during the COVID-19 pandemic with the increasing number of positive people. Several policies are put in place to reduce the positive numbers in Indonesia. Based on this phenomenon, the author then is interested in conducting antecedent research on philanthropic behavior of Jabodetabek communities in the era of COVID-19 pandemic.

\section{LITERATURE REVIEW}

1. Philanthropy

a. Knowledge Gap

Philanthropy with a new version of "Philanthrocapitalism", i.e. sulking at the extent to which personal wealth can advance the public interest by implementing skills, money, and gifts. Experts point out that the $21^{\text {st }}$ century has given people unprecedented wealth, opportunities, and responsibilities to advance the public good (bishop, M. and Green, 2008)

The modern version of Corporate Social Responsibility (CSR) includes the function of philanthropy as its dimension, in addition to economic, legal, and ethical aspects. CSR now plays an important role around the world, as the importance of long-term business survival and success has been well recognized (Caroll, 1991). Philanthropic functions are very important in developing countries, even philanthropy is also referred to as discretionary responsibility as a resource contributed by the company to the objectives of an organization, education, recreation, and culture including the problem of optimizing society.

b. Understanding

Etymological philanthropy refers to the love of mankind, the policy towards the entire human family, and universal good values (Fulton, K, and Blau, 2005). Philosophical philanthropy is a form of the social movement that takes place in the name of God and for the salvation of man (Smith, 1932)

Besides, philanthropy refers to an individual contribution in the form of the kindness of others, to improve the quality of life. As one of the moral responsibilities of individuals to donate money, time, and resources in a certain form (Angela M.Eikenberry, 2005). Besides, philanthropy may refer to an act to lighten the burden and can improve the quality of life of all human beings, which can be measured by volunteerism, concern for others (Cheal, 1986)

c. Philanthropic Behavior Theory

1. Planned Behavior Theory

Planned behavior theory is one of the theories that explain the most comprehensive framework in researching human behavior (Gargani, 2013). This theory has been put forward by Alzen (Alzen, 1991) in his research explaining the intention of a person to perform certain activities or behaviors with the result of his behavioral beliefs. The more controlled and more information about a 
person's behavior, the greater his expectations in predicting philanthropic behavior.

2. Social Identity Approach

This theory tends to consider themselves to be part of the framework of the group or organization in which they are located (Boezeman, E, J. and Ellemers, 2008). As a result of the social identification process, people can develop a sense of psychological attachment to the organization, they will develop themselves openly and motivated (ellemers, N., et al., 2004).

The theory makes it clear that a person will go to great lengths to be philanthropic when tied up in one organization or community. Philanthropic behavior in a person is very bound by people in the same organization and will do the same to his organization (kaskutas, L., A., Bond, et al. 2002). Thus this theory explains the role of social interaction, the influence of organizational friends, and the social role of individuals in encouraging to influence philanthropic behavior among other members of the group.

3. Organizational support theory

The theory of organizational support can be developed from a social perspective to explain organizational relationships (loi, R., et al., 2006). Philanthropic behavior especially in volunteerism is more common in organizations since most members of the organization work voluntarily. It can be concluded that organizational factors are related to the evaluation of respect to increase individual contributions to the organization, one of which is selfinvolvement in philanthropy (Boezeman, E, J. and Ellemers, 2008)

d. Philanthropic Behavior Factors

\section{Individual Factors}

Individual factors are personal intrinsic factors that can influence philanthropic behavior. These factors refer to the motives of individual philanthropic activities, such as providing money, services, and time. Intrinsic factors include selfishness and personality such as extraversion and emotional stability (Kottasz, 2004). Individual factors have variables namely selfishness, extravagance, emotional stability, knowledge, and skills of how an individual performs his philanthropic activities and life.

\section{Social Factors}

Social factors are factors to interact socially, social factors can help humans in conducting philanthropic activities interpersonally (Baumeister, R. F., \& Leary, 1995). And thus a person's involvement in philanthropic activities can be motivated by one of the factors, namely social factors in his social interaction activities with others. Besides, philanthropic activities can be carried out by many people including individuals and groups by providing money, time, and services for their philanthropic interests. (Bryant, W.K., et al. 2003).

\section{Organizational Factors}

Organizational factors are related factors in philanthropic behavior, especially in volunteerism. Organizational factors are connected with formal or informal organizations (Penner, 2002). Organizational factors often occur within an organization to influence an individual's involvement with a group. The organizational factor is one factor in philanthropic behavior with the willingness 
Jurnal Ekonomi dan Perbankan Syariah

Vol. 8. No.2, 0ktober 2020: 41-64, ISSN (cet): 2355-1755 | ISSN (online): 2579-6437

45

of individuals who voluntarily give their time and services, or individuals who contribute money, services, and time to one organization. These factors include the purpose of the organization, the organizational structure in which it has a connection structure in philanthropic activities, and belief in this context is essential to philanthropic behavior, to the giver and recipient of philanthropic assistance.

e. Philanthropic Behavior towards Jabodetabek Community

Charitable behavior is an activity that arises due to stimulus or stimuli coming from outside and from within him with the responsibility to assist the needy. Charitable behavior can be judged from the concept of charity that is proxied in the amount of rupiah issued by respondents to charity (Alawiyah, 2009), in theory, a charity has forms of charitable behavior in Islam consists of zakat, infaq, sadaqah, and wakaf (Veen, 2008)

Religiosity has the power to control beliefs as well as behavior in charity (Machrus, 2010) In general, the people of Jabodetabek refer to those who do philanthropic activities during the COVID-19 pandemic. In this case, Jabodetabek community is the main role in charity and donating assets, services, and time to others to promote philanthropic behavior in the COVID-19 pandemic era.

\section{Pandemic}

According to some experts consider the definition of pandemic is judged based on diseases that can be said to be generally dangerous pandemics, and try to study the disease by examining the similarities and differences. Diseases that can be said to be pandemics can be selected empirically to reflect the etiological spectrum, the spread of mechanisms, and their emergency. Several people have been pandemics: Acute Hemorrhagic Conjunctivitis (AHC), AIDS, Cholera, Dengue Fever, Influenza and SARS (Morens, D.M., Folkers, G. K. and Fauci, 2009)

Most pandemic terms refer to geographically widespread diseases such as, in a series of reviews of pandemic influenza that are said to be geographically categorized into transregional ( 2 regions bordering the world) between yeastonal and global (Taubenberger JK, 2009). Aside from the geographic side, the use of the word pandemic mostly implies the transfer or transmission from one place to another, a striking example today is the Coronavirus Disease (COVID-19) (Lai, A.L., Millet, J.k., Daniel, S., Freed, J.H., \& Whittaker, 2020) covering diseases transmitted from humans to other humans. The appearance of symptoms that mark the transition of the disease from subclinical to clinical. Most diagnoses of the disease are gradual and developing, but in some people the disease process does not survive and develops into a clinically treatable. COVID-19 is a disease that can survive and develop and transmit, the disease process can range from mild or more severe and at risk of fatal if not treated medically. (Atmojo, J., Arradini, D., Ernawati, E., Widiyanto, A., \& Darmayanti, 2020) 
Pandemics will occur if some of these factors occur in the world: (1) an increase in the number of violent of new agents. (2) the information of this new virus has not been detected or is different from previously seen. (3) transmission mode or often called infection is increasing so that the spread of the virus is quickly exposed to each other. (4) changes in the vulnerability of human responses themselves to this new virus. Kelsey JL, 1986

\section{COVID}

Coronavirus is one of the diseases that can be transmitted, a new type of coronavirus called COVID-19 which is found and known as severe acute respiratory syndrome commonly called corona type 2 (SARS-CoV-2). According to many observers of the new type of coronavirus (COVID-19) identified in Wuhan City, China in December 2019 (WHO, 2020).

According to some observers, corona virus is one of the viruses of the type RNA positive single strain, such as capsules and not segmented (Yuliana, 2020). Coronavirus belongs to the order of Nidovirales, the family of coronaviriadae. The structure of the corona virus like a cube with the $S$ protein is located on the surface of the virus. Protein $S$ or also mentioned spirke protein is the main antigen protein in the virus and is the main structure of the virus gene type. This $S$ protein plays a direct role in the virus in order to attach and enter the virus in the host cell (infection of the $\mathrm{S}$ protein with its receptors in the host cell) (wang, Z., Qiang, W., Ke, 2020). Coronavirus is highly sensitive to heat and is effectively activated by disinfectants containing chlorine, lipid solvents that have a temperature of $56^{\circ} \mathrm{c}$ over a period of 30 minutes, ether, alcohol, periocsiasetic acid, non-ionic detergent, formalin, oxidizing agent, and chloroform. Chlorheksidin is not capable of inactivating coronavirus (PDIP, 2020).

According to the World Health Organization (WHO, 2020) coronavirus is generally common in animals and can transmit the disease to animals or humans. Humans diagnosed with infection will pass it on to other humans. Sars-CoV-2 infection will affect the respiratory system such as fever, dry cough, fatigue, pneumonia, even more severe respiratory syndrome (MERS) and severe acute respiratory syndrome (SARS), and multi-organ failure such as kidney and death. (lippi, G., Lavie, C.J. and sanchis-gomar, 2020) The world's huge impact has led to a number of policies to shut down all human activities, who declared COVID-19 to be a global pandemic. (WHO, 2020)

Based on scientific evidence, people who are easily infected by the COVID-19 virus are people who are in direct contact with COVID-19 positive patients such as pashien nurses. Standard recommendations set out to prevent the spread of the COVID-19 virus on the body are by washing hands regularly and cleanly, applying established cough and sneezing ethics, avoiding direct contact with ternah or wild animals, and still avoiding contact with people who show symptoms of respiratory diseases (stones, sneezing). In addition, it must still apply health protocols for infection prevention and control (PPI) (Kemenkes, 2020). 
Jurnal Ekonomi dan Perbankan Syariah

Vol. 8. No.2, 0ktober 2020: 4l-64, ISSN (cet): 2355-1755 | ISSN (online): 2579-6437

47

\section{RESEARCH METHODOLOGY}

This type of research is field research or called empirical research, research that is obtained from data obtained from field activities. The data was obtained by distributing questionnaires to respondents in the study. This research is based on an extensive review of previous research on philanthropic behavior to conduct a review of the library with the keyword of research that is philanthropic.

This research uses descriptive research using data obtained from empirical research. This research is a study of various previous empirical research with a review of the library with a framework that is philanthropic in similar research. To produce new research with new approaches in philanthropic behavior theory by integrating planned behavioral theories such as social approaches, theories, and organizations as well as social networks as mediators proposed in the study.

The population used in this study is Jabodetabek society for objects and subjects that have quality and characteristics. Determining samples in the study is using krejcie and Morgan tables. Krejcie and Morgan in performing sample size calculations are based on a $5 \%$ error. So the sample obtained has $95 \%$ confidence in the population. So sampling refers based on krejcie and morgan table, that is, the number of samples refers based on krejcie and morgan table, which is with a population of between 400 .

As a trace of the formula used by Krejcie and Morgan as follows:

$$
n=\frac{x^{2} \cdot N \cdot P(1-P)}{e^{2}(N-1)+x^{2} P(1-P)}
$$

1) Krejcie and Morgan tables can be used to determine sample sizes, only if the study aims to surmise population proportions.

2) Assuming a constraint rate of $95 \%$, because it uses the value $x^{2}=3,841$ which means to use $0=0.05$ on free drajat 1 .

3) The assumption of population religion included in the calculation is $\mathrm{P}(1$ $\mathrm{P})$, where $\mathrm{P}=0.5$

4) Assumption of $5 \%$ margin of error $(\mathrm{e}=0.05)$

This study used 2 data namely primary data and secondary data. The technique of collecting data using questionnaires conducted by providing a set of questions or written statements to respondents to answer. Efficient data collection techniques so that the author knows exactly the variables to be measured and knows what is expected of the respondents. Questionnaires in this study were used to find data on philanthropic behavior towards the people of Jabodetabek as the respondents targeted in this study. The scale in this study is the likert scale.

Data analysis in this study uses Partial Least Square (PLS) approach. PLS is a component or variant-based structural equation modeling (SEM) equation, model. PLS is an alternative approach that shifts from a covariantbased SEM approach to a variant-based one (Ghozali, 2006b). 
Covariant-based SEM generally tests causality/theory while PLS is a more predictive model. PLS is a powerful method of analysis because it is not based on many assumptions. For example, the data must be distributed normally, the sample does not have to be large other than it can be used to confirm the theory, PLS can also be used to explain whether or not the relationship between latent variables. PLS can simultaneously analyze constructs formed with reflective and formative indicators (Ghozali, 2006b).

The purpose of using PLS is to assist researchers for predicted purposes. Its formal model of defining latent variables is the aggregate linear of its indicators. Weight estimate to create latent variable score component is obtained based on how inner model (structural model that connects between latent variables) and outer model (measurement model that is the relationship between indicator and construct) specified. The result is residual variance of dependent variables (both latent variables and indicators) minimized (Ghozali, 2006b).

Variable measurement is done in the form of a checklist. Each respondent was asked to show their consent or disapproval on each statement scaling between 1 and 5. Respondents' answers were measured using a likert scale consisting of 5 rating points $(5=$ strongly agree, $4=$ agree, $3=$ neutral, $2=$ disagree, $1=$ strongly disagree) .

\section{DISCUSSION}

In this section, there are several pictures in the descriptive section of respondents in the form of gender, age, occupation, domicile, type of philanthropy (charity), and the amount of philanthropy (charity).

\subsection{Gender}

Graph 4.1 Pie Chart Respondent Data By Gender

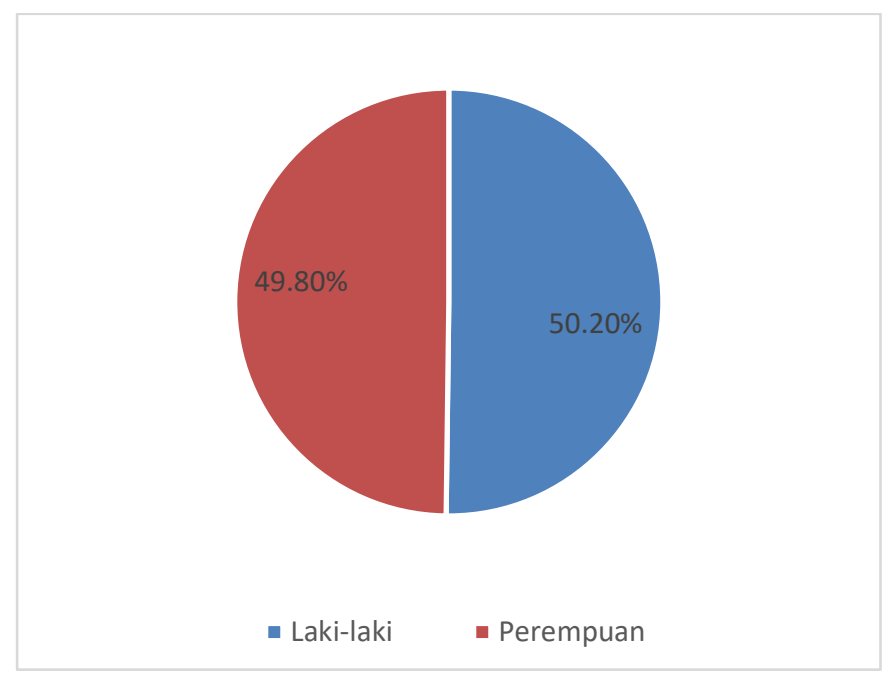


Jurnal Ekonomi dan Perbankan Syariah

Vol. 8. No.2, 0ktober 2020: 4l-64, ISSN (cet): 2355-1755 | ISSN (online): 2579-6437 149

Graph 4.1 shows that of the 400 respondents, the majority are male as much as $50.2 \%$, and female respondents are $49.8 \%$ of respondents.

\subsection{Age of Respondents}

Graph1.2 Pie Chart Respondent Data Based on Respondent's Age

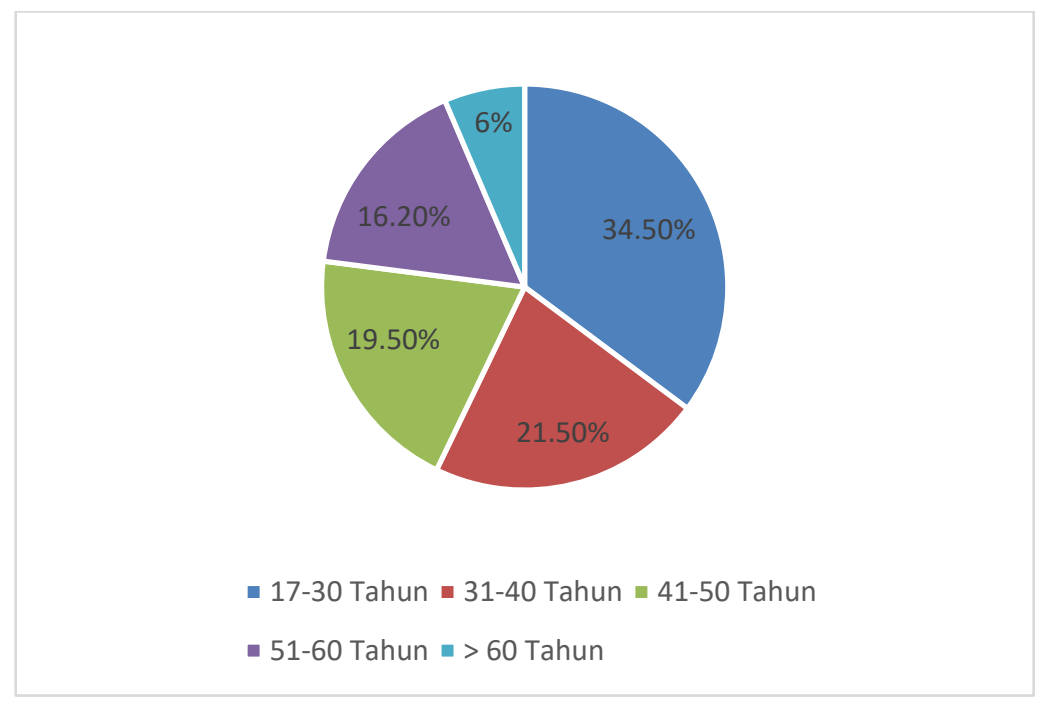

Graph 4.2 shows from 400 respondents, as many as $34.5 \%$ are respondents aged 17-30 years, respondents aged $31-40$ years as much as $21.5 \%$, then respondents aged $41-50$ years as much as $19.5 \%$, then respondents aged 51 60 years with a total of $16.2 \%$, and the age of respondents lebid day 60 years as much as $6 \%$. 
50 | Ida Faridatul Hasanah, Donny Setiawan, Nining Nurhasanah: Antecedents 0f Philanthropic Behavior of People Living In Jabodetabek During Covid-19 Pandemic

\subsection{Respondents' Jobs}

Graph 4.3 Pie Chart Respondent Data Based on Respondents' Work

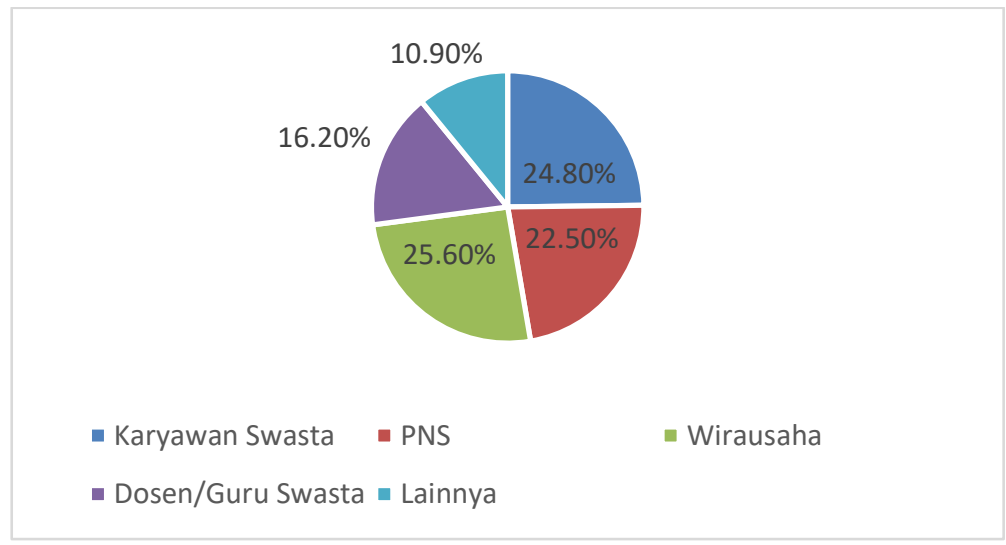

Graph 4.3 shows from 400 respondents, as many as $24.8 \%$ are respondents of private employee workers, civil servant worker respondents as much as $22.5 \%$, then respondents of Entrepreneurial workers as much as $25.6 \%$, then respondents of Lecturers / Private Teachers with the number of $16.2 \%$, and respondents with other jobs as much as $10.9 \%$.

\subsection{Domicile of Respondents}

Graph 4.4 Pie Chart Respondent Data Based on Respondent Domicile

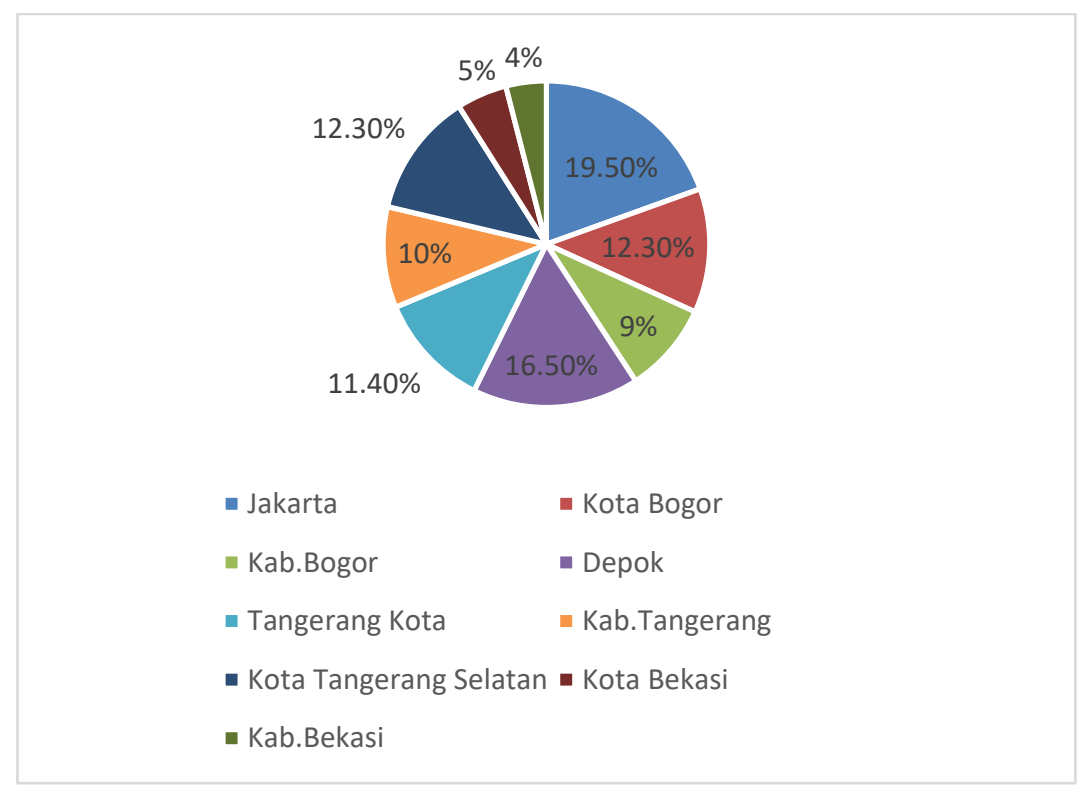


Jurnal Ekonomi dan Perbankan Syariah

Vol. 8. No.2, 0ktober 2020: 41-64, ISSN (cet): 2355-1755 | ISSN (online): 2579-6437

| 51

Graph 4.4 shows from 400 respondents, as many as $19.5 \%$ are respondents domiciled in Jakarta, respondents domiciled in Bogor City as much as $12.3 \%$, then respondents domiciled in Bogor Kab.Bogor as much as 9\%, then respondents domiciled in Depok with the number of $16.5 \%$, and respondents domiciled in Tangerang city as much as $11.4 \%$, domicile Kab.Tangerang as much as $10 \%$, then domicile of South Tangerang City as much as $12.3 \%$, and domicile of Bekasi City as much as 5\%, and domicile of Bekasi City as much as $5 \%$, and domicile of Bekasi City as much as $5 \%$, and domicile of Bekasi City as much as 5\%, and domicile of Bekasi City as much as 5\%, and domicile of Bekasi City as much as 5\%, and domiciled in Bekasi City as much as 5\%, and domiciled in Bekasi City as much as 5\%

\subsection{Types of Philanthropy (Charity)}

\section{Graph 4.5 Pie Chart Respondent Data By Philanthropy Type (Charity)}

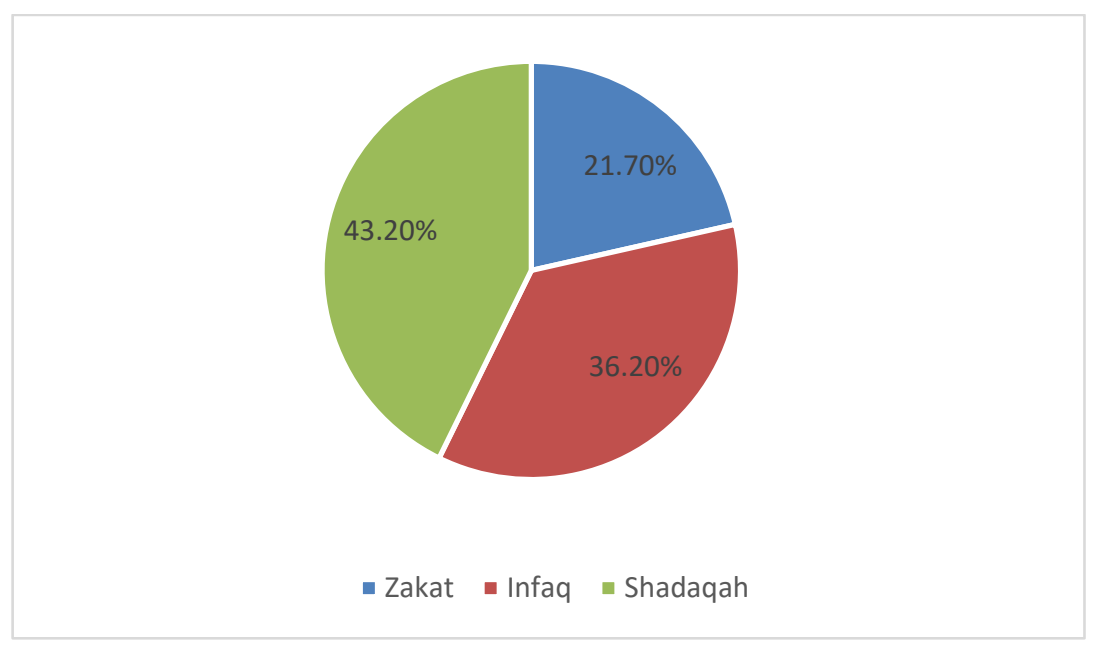

Graph 4.5 shows from 400 respondents, as many as $21.7 \%$ of respondents are different, and as many as $36.2 \%$ of respondents do infaq, then respondents with a limit of $43.2 \%$ 
52 | Ida Faridatul Hasanah, Donny Setiawan, Nining Nurhasanah: Antecedents of Philanthropic Behavior of People Living In Jabodetabek During Covid-19 Pandemic

\subsection{Amount of Rupiah Philanthropy (Charity)}

\section{Graph 4.6 Pie Chart Data Based on The Amount of Rupiah Philanthropy (Charity)}
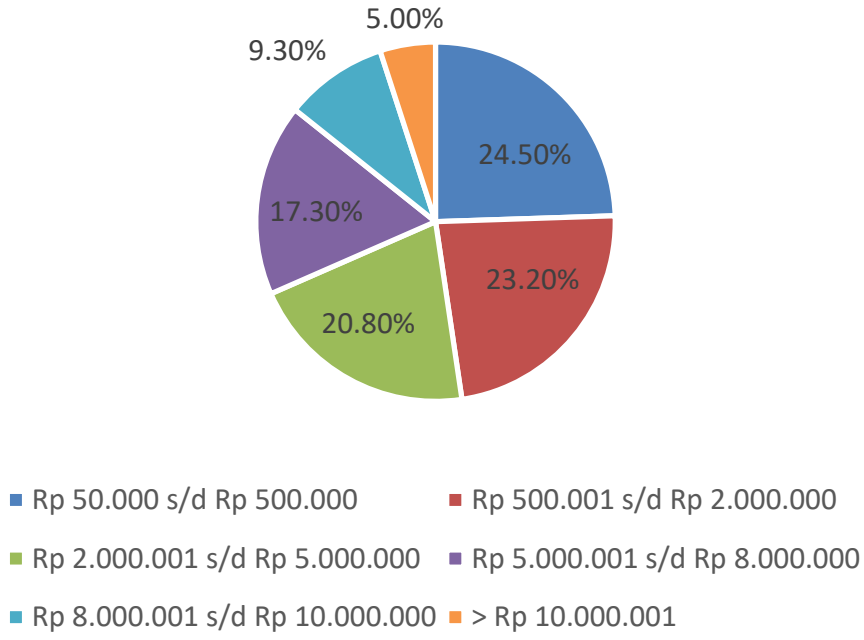

Graph 4.6 shows from 400 respondents, as many as $24.5 \%$ are respondents with the amount of $\mathrm{Rp} 50,000$ to $\% 500,000$, respondents with the amount of $\operatorname{Rp~500,001~to~2,000,000~as~much~as~} 23.1 \%$, furthermore, respondents with the amount of $\operatorname{Rp} 2,000,001$ to $\mathrm{Rp} 5,000,000$ as much as $20.8 \%$, then respondents with the amount of $\operatorname{Rp} 5,000,001$ to Rp 8,000,000 as much as 17.3\%, and respondents with the amount of $\mathrm{Rp} 8,000,001$ to $\mathrm{Rp} 10,000,000$ as much as $9.3 \%$, and the amount of more than $10,000,001$ as much as $5 \%$,

\subsection{VALIDITY TEST}

Test the validity of questionnaire data as part of the evaluation of the measurement model by using loading factor parameters, average variance extracted (AVE), discriminant validity. To test the validity of data assisted with SmartPLS program using the method "PLS Algorithm"

\subsubsection{Convergent Validity}

Convergent validity is performed to measure the magnitude of the correlation between the contract and the latent variable so that it is known whether a measuring variable should be measured. Evaluation of convergent validity begins with an individual inspection of reliability items that can be seen from the standard value of the loading factor. The loading factor value above 0.7 can be said to be ideal which illustrates that the indicator is said to be valid as an indicator that measures the construct. While the loading factor value below 0.7 will be omitted in the model. The result of the loading factor can be seen in the following image: 
Jurnal Ekonomi dan Perbankan Syariah

Vol. 8. No.2, 0ktober 2020: 4l-64, ISSN (cet): 2355-1755 | ISSN (online): 2579-6437

53

\subsubsection{Loading Factor Results}

Figure 4. 1 Loading Factor Results

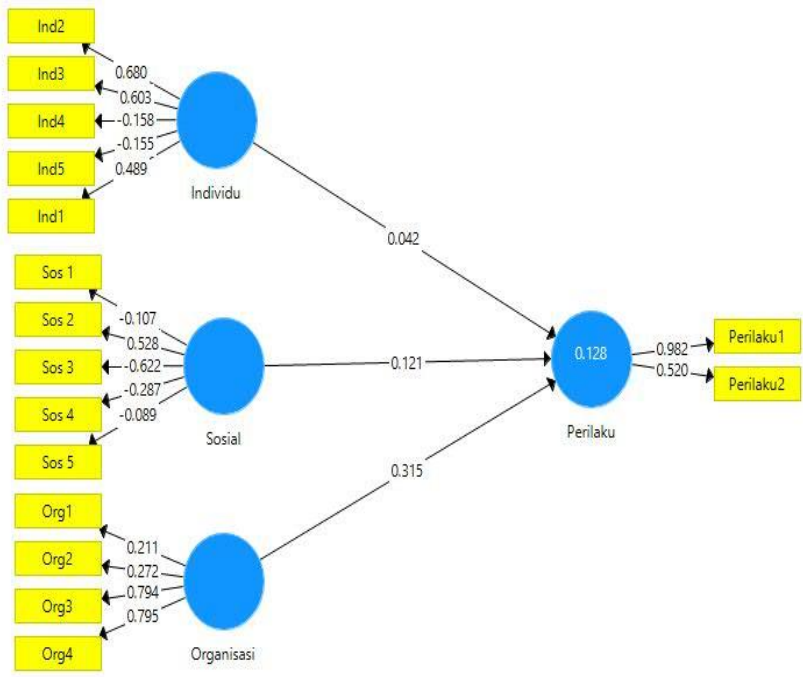

Source: Data processed using SmartPLS

Based on the visible figure that there are 16 indicators in this study, there are 10 indicators that are not valid because they do not meet the loading factor criteria (values below 0.7). So that the next data validity test by eliminating the invalid indicator.

Figure 4. 2 Retest results

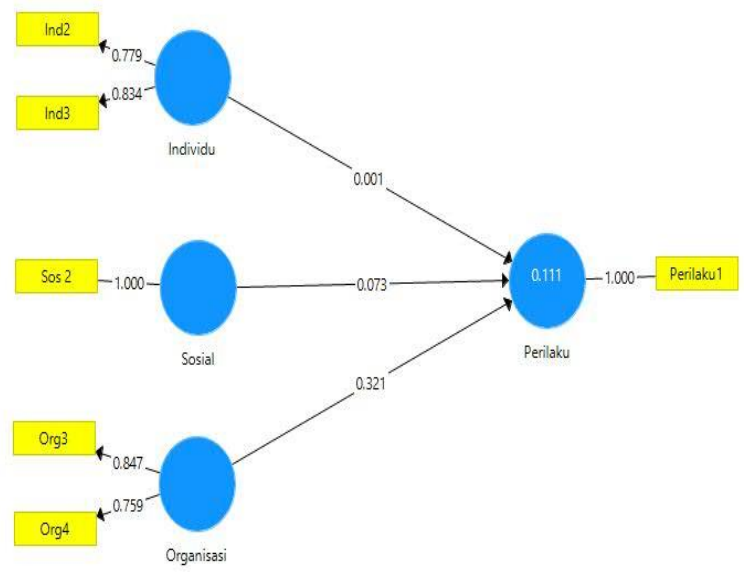


54 | Ida Faridatul Hasanah, Donny Setiawan, Nining Nurhasanah: Antecedents 0f Philanthropic Behavior of People Living In Jabodetabek During Covid-19 Pandemic

\section{Source: Data processed using SmartPLS}

In the picture can be seen that retesting produces a loading factor value on all indicators above 0.7 . Which has been done 10 valid indicators and done re-processing, so all indicators in this study declared valid.

\subsubsection{Average Variance Extracted (AVE)}

Average Variance Extracted (AVE) shows the average percentage of variant scores extracted from latent variable devices estimated through-loading standardize indicators in the process of iteration algorithms in PLS. Based on ave value declared valid if more than 0.5 .

Table 4.1 Validity Test Results with Average Variance Extracted (AVE) Parameters

\begin{tabular}{|c|c|c|}
\hline Variable & Average Variance Extracted (AVE) & Description \\
\hline Individual & 0,651 & Valid \\
\hline Organization & 0,647 & Valid \\
\hline Behavior & 1,000 & Valid \\
\hline Social & 1,000 & Valid \\
\hline
\end{tabular}

Source : OutputSmartPLS 3.0, 2020

Table 4.1 All latent variables meet the Average Variance Extracted (AVE) value criteria of more than 0.5 so that all latent variables can be declared valid.

\subsubsection{Discriminant Validity}

Discriminant Validity in subsequent tests relates to the principle on measurements (manifest variables) there are different constructs, should not communicate with height. Another method to assess the validity of the discriminant is to compare the square root of the AVE (AverageVariance Extracted)of each construct with the correlation between the construction and other constructs in the model. The model has sufficient discriminant validity if the AVE root (AverageVariance Extracted)is greater than the correlation of other latent variables, then the variable is said to be valid. Next is Table 4.2 which shows the results of the estimated latent calculation of correlation variables.

Table 4.2 Latent Variable Correlation

\begin{tabular}{|c|c|c|c|c|}
\hline & Individual & Organization & Behavior & Social \\
\hline Individual & 1,000 & 0,102 & 0,038 & 0,056 \\
\hline Organization & 0,102 & 1,000 & 0,325 & 0,042 \\
\hline Behavior & 0,038 & 0,325 & 1,000 & 0,087 \\
\hline Social & 0,056 & 0,042 & 0,087 & 1,000 \\
\hline
\end{tabular}

Source: Data processed using SmartPLS

Based on table 4. 2 above it is known that ave root generally has a higher value than the correlation between latent variables. So it can be concluded 
Jurnal Ekonomi dan Perbankan Syariah

Vol. 8. No.2, 0ktober 2020: 4l-64, ISSN (cet): 2355-1755 | ISSN (online): 2579-6437

\section{5}

that the model has a good discriminant validity so that it can be continued to the next stage.

\subsection{RELIABILITY TEST}

Reliability test questionnaire data as part of the evaluation of measurement model (outer model)is carried out under the criteria stated in Table 3. 3 which is by using composite reliability and Cronbach's alpha. To test the validity of the data is assisted with the SmartPLS program by using the method "PLS Algorithm".

\subsubsection{Composite Reliability}

Composite reliability is one of the values that measure internalconsistencyof a latent variable. Latent variables are declared reliable if they have a composite reliability value of more than 0.7 .

Table 4.3 Reliability Test Results with Composite Reliability Parameters

\begin{tabular}{|c|c|c|}
\hline Variable & Composite Reliability & Conclusion \\
\hline Individual & 0,789 & Reliabel \\
\hline Organization & 0,785 & Reliabel \\
\hline Behavior & 1,000 & Reliabel \\
\hline Social & 1,000 & Reliabel \\
\hline
\end{tabular}

Source: Data processed using SmartPLS

The following Table 4.3 all variables meet the composite reliability criteria. So that all variables are declared reliabel.

\subsubsection{Cronbach's Alpha}

Cronbach's Alpha is one of the values that measures the internal consistency of a latent variable. Latent variables can be declared variable if cronbach's alpha value is greater than 0.7 .

Table 4.4 Reliability Test Results using Cronbach's Alpha Parameters

\begin{tabular}{|c|c|c|}
\hline Variable & Cronbach's Alpha & Conclusion \\
\hline Individual & $\mathbf{0 , 4 6 7}$ & Not Reliabel \\
\hline Organization & $\mathbf{0 , 4 5 7}$ & Not Reliabel \\
\hline Behavior & $\mathbf{1 , 0 0 0}$ & Reliabel \\
\hline Social & $\mathbf{1 , 0 0 0}$ & Reliabel \\
\hline
\end{tabular}

\section{Source: Data processed using SmartPLS}

The following in Table 4.4 some variables that do not meet Cronbach's Alpha criteria. There are Individual and Organization variables that do not meet the criteria, so the variable is declared not reliable. The other two variables meet Cronbach's Alpha criteria so that variables can be declared variables. 
56 | Ida Faridatul Hasanah, Donny Setiawan, Nining Nurhasanah: Antecedents 0f Philanthropic Behavior of People Living In Jabodetabek During Covid-19 Pandemic

\subsection{TEST STRUCTURAL MODEL (INNER MODEL)}

In the inner model or structural model, testing was conducted to see the relationship between construction, significance value, and $R$-Square of the research model. Structural models are evaluated using $R$-square for t-test dependent constructs as well as the significance of structural path parameter coefficients.

\subsubsection{R-Square $\left(\mathbf{R}^{2}\right)$}

Table 4.5 R-Square

\begin{tabular}{|c|c|}
\hline Variable & R Square \\
\hline Behavior & 0,111 \\
\hline
\end{tabular}

Source: Data processed using SmartPLS

In Table $4.5 R$-Square this study used 1 variable that was influenced by other variables namely Behavior variables that were influenced by Individual variables, organizational variables, and social variables. The R-square value of the Behavior variable is 0.111 categorized as strong because $>0.7$.

Table 4.5 shows the $R$-Square value for the behavior variable obtained is 0.111 . These results showed that $11.1 \%$ of behavior variables were influenced by individual variables, organizational variables, and social variables.

4.6MODEL FIT

Table 4.6 Fit Summary

\begin{tabular}{|l|c|c|}
\hline & Saturated Model & Estimated Model \\
\hline SRMR & 0,10 & 0,110 \\
\hline d_ULS & 0,252 & 0,252 \\
\hline d_G & 0,102 & 0,102 \\
\hline Chi-Square & 267,160 & 267,160 \\
\hline NFI & $-0,962$ & $-0,962$ \\
\hline
\end{tabular}

Source: Data processed using SmartPLS

Fit Model with Standardized Root Mean Square Residual (SRMR). SRMR is a corporation between the observed correlation and the implied correlation matrix model. Thus, it is possible to assess the average size of the difference between the observed correlation and the expected absolute measure of the model match criteria (Bentler, P.M., \& Bonett, 1980)

In model measurements for models to meet fit model criteria, the SRMR value must be more than 0.10 or 0.08 introduces SRMR as a goodness of fit measure for SEM-PLS that can be used to avoid model specification errors. 
Jurnal Ekonomi dan Perbankan Syariah

Vol. 8. No.2, 0ktober 2020: 41-64, ISSN (cet): 2355-1755 | ISSN (online): 2579-6437

$\mathbf{5 7}$

Furthermore, Table 4.6 shows that the SRMR value meets the fit model criteria which must be less than 0.10 or 0.08 meaning that this research is considered suitable or good.

\subsection{HYPOTHESIS TESTING WITH PATH COEFFICIENTS}

\subsubsection{Path Coefficients}

Path Coefficients is used to examine the significance of the relationship between latent variables and bootstrapping resulting $t$-static values (in SmartPLS programs produce $\mathrm{p}$-value). The $t$-statistic value will be compared to $\mathrm{t}$-table. If the value of t-statistic is greater than t-table (or p-value $\leq \alpha$ ) then the associated variable is declared to have a significant effect. For level of confidence of $95 \%((\alpha=5 \%)$, then used $t$-table as a reference of 1,960. Positive values in path coefficient indicate that the associated variables have a positive effect, on the contrary if the path value is coefficient negative then the associated variable negatively affects.

Table 4.7 Results Path Coefficients Model Bootstrapping

\begin{tabular}{|l|l|l|l|l|l|}
\hline & $\begin{array}{l}\text { Original } \\
\text { Sample } \\
(\mathrm{O})\end{array}$ & $\begin{array}{l}\text { Sample } \\
\text { Mean } \\
(\mathrm{M})\end{array}$ & $\begin{array}{l}\text { Standard } \\
\text { Deviation } \\
(\text { STDEV) }\end{array}$ & $\begin{array}{l}\text { T Statistics } \\
(\mid \\
\text { O/STDEV| })\end{array}$ & $\begin{array}{l}\text { P } \\
\text { Values }\end{array}$ \\
\hline $\begin{array}{l}\text { Individual => } \\
\text { Behavior }\end{array}$ & 0,001 & 0,007 & 0,073 & 0,019 & 0,985 \\
\hline $\begin{array}{l}\text { Organisai => } \\
\text { Behavior }\end{array}$ & 0,321 & 0,328 & 0,061 & 5,304 & 0,000 \\
\hline $\begin{array}{l}\text { Social => } \\
\text { Behavior }\end{array}$ & 0,073 & 0,073 & 0,066 & 1,102 & 0,271 \\
\hline
\end{tabular}

Source: Data processed using SmartPLS

\section{Hypothesis I Testing (Individuals have a positive and significant effect on philanthropic behavior)}

The results of the first hypothesis test showed that the relationship of individual variables showed a path coefficient value of 0.001 with a $t$-statistic value of 0.019 . The $t$-statistic value is less than the t-table $(1,960)$. These results mean that individuals have a negative and insignificant relationship to philanthropic behavior which means it does not conform to the first hypothesis where individual control encourages society in conducting philanthropic behavior. This means Hypothesis I is rejected.

\section{Hypothesis II Testing (Organization positively and significantly affects philanthropic behavior)}

The results of the second hypothesis test showed that the relationship of organizational variables with philanthropic behavior showed a path coefficient value of 0.321 with at-statistic value of 5.304. The t-statistic value is greater than the table $\mathrm{t}-(1,960)$. These results mean that organizations have a 
58 Ida Faridatul Hasanah, Donny Setiawan, Nining Nurhasanah: Antecedents of Philanthropic Behavior of People Living In Jabodetabek During Covid-19 Pandemic

positive and significant relationship to philanthropic behavior. This means hypothesis II is accepted

\section{Hypothesis III Testing (Social positive and significant effect on philanthropic behavior)}

The results of the third hypothesis test showed that the relationship of social variables showed a path coefficient value of 0.073 with a $t$-statistic value of 0.102 . The $t$-statistic value is less than the t-table $(1,960)$. These results mean that social has a negative and insignificant relationship to philanthropic behavior which means it does not conform to the first hypothesis where individual control encourages society in conducting philanthropic behavior. This means hypothesis III is rejected.

Discussion

Test results on the hypothesis of direct influence of research developed, based on the results of testing using Smart PLS3.0 there are 1 (one)hypothesis received and 2 (two)hypotheses that are rejected.

Table 4.8 Results of Hypothesis Test Recapitulation

\begin{tabular}{|c|l|c|}
\hline Hypothesis & \multicolumn{1}{|c|}{ Statement } & Results \\
\hline H1 & $\begin{array}{l}\text { Individual variables have a } \\
\text { significant positive effect on } \\
\text { philanthropic behavior }\end{array}$ & Hypothesis rejected \\
\hline H2 & $\begin{array}{l}\text { Organizational variables have a } \\
\text { significant positive effect on } \\
\text { philanthropic behavior }\end{array}$ & $\begin{array}{c}\text { Hypothesis } \\
\text { accepted }\end{array}$ \\
\hline H3 & $\begin{array}{l}\text { Social Variables have a } \\
\text { significant positive effect on } \\
\text { philanthropic behavior }\end{array}$ & Hypothesis rejected \\
\hline
\end{tabular}

1. Individuals have a positive relationship and have a significant influence on the philanthropic behavior of the community

The first hypothesis (H1) states that individual variables have a positive effect on people's philanthropic behavior is rejected. Based on the results of the resampling bootstrapping test obtained a coefficient parameter value of 0.001 with a t-statistic value of 0.019 . This points out that individual variables have no significant effect on people's philanthropic behavior, based on the value of t-statistic $<1,960$. In addition, the influence of individual variables on philanthropic behavior is negative because the value of the coefficient parameters is negative. So it can be concluded that individual variables have no significant effect on the philanthropic behavior of the community.

The results of this study show there is no positive and significant effect between individual variables on the philanthropic behavior of the community. Although statistically the results of individual variables are stated to not affect the philanthropic behavior of the community. As previously 
Jurnal Ekonomi dan Perbankan Syariah

Vol. 8. No.2, 0ktober 2020: 4l-64, ISSN (cet): 2355-1755 | ISSN (online): 2579-6437

\section{9}

stated, that the lack of influence between individual variables and philanthropic behavior (charity) does not mean showing the importance of charitable principles in each individual, but it can be possible that the people of Jabodetabek by strengthening the principle of charity during the COVID-19 pandemic.

\section{Organizations have a positive relationship and have a significant} influence on the philanthropic behavior of the community

The second hypothesis $(\mathrm{H} 2)$ states that organizational variables directly affect the philanthropic behavior of the People of Jabodetabek is acceptable. Based on resampling bootstrapping test results obtained a coefficient parameter value of 0.321 with at-static value of 5,304. This indicates that organizational variables have a significant effect on the philanthropic behavior of the Jabodetabek community, due to the value of t-statistic $>1,960$. Besides, the influence of organizations on philanthropic behavior in Jabodetabek communities is positive because the value of coefficient parameters is positive. So that it can be concluded that organizational variables have a positive and significant effect on philanthropic behavior in the Jabodetabek community.

Organizations have a positive influence on philanthropic behavior in Jabodetabek communities is a place that has a great influence on other communities in behaving charitably during the COVID-19 pandemic. The organization is an influential factor based on humanity to show a sense of desire to share with others in this pandemic. The belief to do charitable activities is normative and motivates other people to act with the same thing. The influence of organizations on philanthropic or charitable behavior is greater and the broader the influence given and received by the community, the higher this influence is greater convincing other people in terms of sharing or charity towards others.

\section{Social relationships have a positive relationship and have a significant influence on the philanthropic behavior of the community}

The third hypothesis (H3) states that social variables have a positive effect and on philanthropic behavior in Jabodetabek communities are rejected. Based on the results of the resampling bootstrapping test obtained a coefficient parameter value of 0.073 with a t-statistic value of 1.102 . This indicates that social variables do not have a significant effect on the philanthropic behavior of the Jabodetabek community due to the value of t-statistic $<1,960$. Besides, the social influence on the philanthropic behavior of Jabodetabek society is negative because the value of the coefficient parameters is negative. So that it can be concluded that social variables do not have a significant and negative effect on philanthropic behavior in the Jabodetabek community.

The test results showed that social variables have a negative and insignificant effect on philanthropic behavior in Jabodetabek communities. Social influence is a factor that applies the morality of a person in society to charity or philanthropic behavior towards others, to apply the values of kindness 
60 | Ida Faridatul Hasanah, Donny Setiawan, Nining Nurhasanah: Antecedents 0f Philanthropic Behavior of People Living In Jabodetabek During Covid-19 Pandemic

to others and apply a sense of concern among others. However, applying and improving social values to charitable activities or philanthropic behavior is very important during the COVID-19 pandemic which is very influential on people in need.

\section{CONCLUSION}

This study aims to analyze the influence on individual, organizational and social variables on philanthropic or charitable behavior in Jabodetabek communities as objects in research. In this study, it was divided into 2 (two) variables, namely exogenous variables and endogenous variables. In analyzing this study using Partial Least Square (PLS), as for the results of the analysis anddiscussion of 2 (two) related variables previously, the researchers concluded that:

1) Individual factors do not affect philanthropic behavior (charity) in Jabodetabek communities during the COVID-19 pandemic. This is indicated by the analysis that the t-statistic value owned is less than the t-table $(0,019<1,960)$ and the significance value is greater than the value of $5 \%$ significance $(0.985>0.05)$. This suggests that the first hypothesis was rejected.

2) Organizational factors have a positive and significant effect on philanthropic behavior (charity) in Jabodetabek communities during the COVID-19 pandemic. This is indicated by the coefficient value of positive value of 0,321 and t-statistic value that has a value greater than t-table $(5,304>1,960)$ and a significance value that is less than the value of significance of $5 \%(0.000<0.05)$. These results suggest that a second hypothesis is accepted.

3) Social Factors have no effect on philanthropic behavior (charity) in Jabodetabek communities during the COVID-19 pandemic. This is indicated by the analysis of the coefficient value of 0.073 and the value of t-statistic owned is less than t-table $(1,102<1,960)$ and the value of significance greater than the value of significance of $5 \%(0.271>$ 0.05). This suggests that the third hypothesis was rejected.

\section{REFERENCES}

(ILO)., O. P. I. (2020). Technical and ethical guidelines for the supervision of workers' health. Occupational Safety and Health Series No. 72.

Abdillah, W., \& Hartono, J. (2015). Partial Least Square (PLS)- Alternative Structural Equation Modeling (SEM) in Business Research. (D. Prabantini, Ed.) . Andi offset.

Alam, N. (2010). islamic venture philanthropy: a tool for sustainable community.

Alawiyah, T. (2009). Correlation of Charitable Acts with the Nominal Amount of Indonesian Muslims". Zakat \& Empowering Journal of Thought 
Jurnal Ekonomi dan Perbankan Syariah

Vol. 8. No.2, 0ktober 2020: 4l-64, ISSN (cet): 2355-1755 | ISSN (online): 2579-6437

| 61

andIdeas, II.

Alias, S. N., \& Ismail, M. (2013). Conceptualizing Philanthropic Behaviour and Its Antecedents of Volunteers in Health Care Graduate Research In Education ( Greduc 2013 ) Conceptualizing Philanthropic Behavior And Its Antecedents Of Volunteers Siti Noormi Alias \& Maimunah Ismail. (April 2014).

Alzen, I. (1991). the theory of planned behavior. organization behavior and human decision processes, 50 No. 2, 179-211.

Andrews, B. A. K. (1987). AATCC Test Method 112. An update on testing for formaldehyde release.

Angela M.Eikenberry. (2005). philantropy, voluntary association, and governance beyond the state, administrtion society.

Anniss, Y. N. R. \& R. (2020). Lock Down Enforcement Policy In Anticipation of the Spread of Corona Virus Covid-19.

Anshori Muslich, S... (2017). quantitative research methodology (issue 2). Surabaya: Airlangga univerity press.

Atmojo, J., Arradini, D., Ernawati, E., Widiyanto, A., \& Darmayanti, A. (2020). cardiopulmonary resuscitation in the COVID-19 pandemic era. journal ofnursing, 12 13, 355-362.

Well left, R. (2020). Changes in Indonesian Consumer Shopping Behavior During Covid-19.

Baumeister, R. F., \& Leary, M. R. (1995). The need to belong: Desire for interpersonal attachments as a fundamental human motivation. Psychological Bulletin, 117 No.3, 497.

Bentler, P.M., \& Bonett, D. (1980). Significance Tests and Goodness-of-Fit in the Analysis of Covariance Stuctures. Psychological BUlletin.

bishop, M. and Green, M. (2008). philantropicalism: how the rich can save the world, bloomsbury press. london.

Boezeman, E, J. and Ellemers, N. (2008). volunteer recruitment: the role of organization support and anticipated respect in non-volunteers attraction to charitable volunteer organizations. journal of applied psychology, g3 No. 5, 1013-1026.

Bremer, J. (2004). islamic philanthropy: reviving traditional forms for building social justice. CSID Fifthy annual conference: cdefinig and establishing justice in muslim societies, university of nerth caroliona, chapel hill, Washington, DC, 1-26.

bryant, W.K., Jeon-Slaughter, H., Kang, H, and Tax, A. (2003). participation in philanthropic activities: donating money and time. journal of consumer policy, 26 No. 1, 43-73.

Caroll, A. B. (1991). the pyramid of corporate social responsibility: toeard the moral management of organization stakeholders. business horizons, 34 No. 4, 39-48.

Cheal, D. . (1986). The social dimensions of gift behaviour. journal of social and personal relationship, 58 No.6, 1015-1026.

Coronavirus, P., \& Kegiatan, I. (2020). Coronavirus Disease Coronavirus 
62 | Ida Faridatul Hasanah, Donny Setiawan, Nining Nurhasanah: Antecedents 0f Philanthropic Behavior of People Living In Jabodetabek During Covid-19 Pandemic

\section{Disease Situation World Health World Health Organization} Organization. 19, 1-12.

Dewi Nari Ratih Permada, Ugeng Budi Haryoko, Enny Savitri, A. S., \& Sunardi, D. (2020). Marketing Strategy of Amil Zakat Nahwa Nur Institute to Increase Donors During the Covid-19 Pandemic In Cibinong, Bogor, West Java. 1(3), 41-47.

ellemers, N., De Gilder, d, and Haslam, S. A. (2004). Motivating individualis and group: a social identity perspective on leadership and group performance. academy of management review, 29 No. 3, 459-478.

Fathoni, A. (2020). Impact of COVIC 19 And Government PSBB Policy on MSMEs in Wiyung Surabaya. economy, 2507(1), 1-9.

fehr, A.R., Perlman, S. (2015). coronavirus: an overview of their replication and pathogenesis,. Methods Mol Biol, 1-5.

Fulton, K and Blau, A. (2005). cultivating change in philanthropy: A working paper on how to create a better future monitor company, LLP.

Gargani, J. (2013). what can practitioners leaarn from theorists logic models? evaluation and program planning, 38 No. 1, 81-88.

Ghozali, I. (2006). Stuctural Equation Modelling: Alternative Method with PARTIAL LEAST SQUARES (PLS). Diponogoro University.

Hadi, S. (2001). methodology of research volumeIII. Yogyakarta: Andi offset.

Hanoatubun, S., Kristen, U., Wacana, S., \& Indonesia, P. (2020). Impact of COVID-19 on Indonesia's Economy. 2,146-153.

Henseler, J. (2014). Common Beliefs and Reality abaout Partial Least Squares: Comments on Ronkko \& Evermann (2013).

huang, C,. Wang, Y., Li, X., Ren, L., Zhao, J., Zan, G Li., Fan, G. (2020). clinical features of pantients infeceted with 2019 novel coronavirus in Wuhan, China. The lancet 24 jan 2020.

Indonesia, the D. P. Society (2020). clinical practice guide: pneumonia 2019nCoV. In PDIP. Jakarta, Jakarta.

Jamaluddin, I. I. (2020). Cyber Media Responds to Public Solidarity Affected by Covid-19 in Palu, Central Sulawesi. (440), 37-51.

kaskutas, L., A., Bond, J. and Humphreys, K. (2002). No Titlesocial networks of the effect of alcoholics anonymous. addiction, 97 No. 7, 891-900.

kelsey JL, T. W. (1986). methods in observational epidemiology, New York. New York: Evans AS.

Ministry of Health. (2020). Guidelines for covid-19 preparedness. COVID-19 preparedness guidelines, $0-115$.

Ketchen, D. J. (2013). A Primer on Partial Least Squares Structural Equation Modeling. Long Range Planning.

Kottasz, R. (2004). Differences in the donor behavior characteristics of young affluent males and felames: Empirical evidence from Britain. International Journal of Voluntary and Nonprofit Organizations, 15 No.2, 181.

Lai, A.L., Millet, J.k., Daniel, S., Freed, J.H., \& Whittaker, G. . (2020). since january 2020 elsevier has created a COVID-19 resaurce centre with free information in english and mandarin on the novel coronavirus COVID- 
Jurnal Ekonomi dan Perbankan Syariah

Vol. 8. No.2, 0ktober 2020: 4l-64, ISSN (cet): 2355-1755 | ISSN (online): 2579-6437

| 63

19 cmpany. 395, 1315.

Latief, H. (2013). Religion and Social Services: Interpretation and Action of Philanthropy in Muslim and Christian Traditions in Indonesia. Journal ofReligion , IX No.2,179.

lindskold, S., Forte, R.A., Haake, C.S. and Schimidt, E. . (1977). the effect of direcness of face-to-face requests and sex of solicitor onstreet corner donations. the journal of social psychology, 101 No. 1, 45-51.

lippi, G., Lavie, C.J. and sanchis-gomar, F. (2020). cardiac troponin I in patiients with coronavirus disease 2019 (COVID-19). progress in cardiovascular disease, 10.

loi, R., Ngo, H.Y. and Foley, S. (2006). linking employees justice perceptions to organizational commitment and intentio to leave: the medicating role of perceived organizational support. journal of occupational and organizational psychology, 79 No. 1, 101-120.

Machrus, H. and U. P. (2010). Behavioral Measurement Based on Theory of Planned Behavior", Department of Personality and Social Psychology Faculty of Psychology Universitas Airlangga, Jl.Dharmawangsa Dalam Selatan Surabaya. INSAN. 12 No.01.

Maduningtias, L. (2020). Strengthening Ukhuwah Through Sharing Among Others Affected by COVID-19. 1(1), 117-122.

Maulida, S. (2013). The influence of religiosity on charitable behavior in yogyakarta city. journal of Indonesian ShariaEconomics, III(1), 1-16.

McLean, G.N., Kou, M.H., Budhwani, N, N., Yamnill, S. and Virakul, B. (2012). capacity building for societal development: case studies in human resource development. Advances in Developing Human Resources, 14 No.3, 251-263.

Mohd Zakaria, A., Abd. Samad, R. and Shafii, Z. (2012). venture philanthropywaqf practices and its implementation: scenario in Malaysia. international journal of business economics, and law, 40 No. 7, 17981818.

Morens, D.M., Folkers, G. K. and Fauci, A. . (2007). What is a Pandemic? the journal of infectious diseases, 10 No 1086, 1018-1021.

Muhammad, S. (2020). zakat fundraising strategy: opportunities and challenges in digital era. of nahdatul ulama stidies, 1.

Murti, B. (2020). principles and methods of epidemiological research. 714842-0,978.

Nurhidayat, N. (2020). Zakat Fundraising Strategy After the Covid-19 Pandemic. SALAM: Syar-i Social and Cultural Journal, 7(8), 737-748. https://doi.org/10.15408/sjsbs.v7i8.16553

Nurhidayati. (2020). the economy of Ramadan in the midst of the COVID-19 outbreak. (covid-19 outbreak), 13.

Penner, L. A. (2002). Dispositional and organizational influences on sustained volunteerism: An interactionist perspective. Journal of Social Issues, 58 No.3, 447.

Pramana, C., \& Semarang, U. N. (2020). Are Doctors Ready to Face pandemic 
64 | Ida Faridatul Hasanah, Donny Setiawan, Nining Nurhasanah: Antecedents 0f Philanthropic Behavior of People Living In Jabodetabek During Covid-19 Pandemic
due
to
Covid-19.
(March),
$0-6$.

https://doi.org/10.13140/RG.2.2.35338.62402

Prasada, D., Hermawan, H., \& Ismanto, B. (2020). Donation of Pamulang University Lecturers to Babakan Setu Residents Affected by Covid 19 In Cooperation with MSMEs Babakan Setu South Tangerang. 2(2), 114118.

Rahmadia, S., Febriyani, N., Kuala, U.S., Islam, J. E., \& Kuala, U. S. (2020). The impact of covid-19 on the economy.

Ryeder, G. (2020). COVID-19 has exposed the fragility of our economy. International Labour Organization. Jakarta, Jakarta.

Sihaloho, E. D., \& Padjadjaran, U. (2020). The Impact of Covid-19 on the Indonesian Economy The Impact of Covid-19 on the Indonesian Economy. (April). https://doi.org/10.13140/RG.2.2.13651.94241/1's https://doi.org/10.13140/RG.2.2.13651.94241/1

Smith, T. V. (1932). Herbert mead and the philosophy of philanthropy. social service review, 6 No.1, 37-54.

Sugiyono, I'm sorry. (2007). statistics for research. Bandung: Alfabeta.

Sugiyono, P. D. quantitative research method, qualitative, and R\&D. , Alfabeta, cv. (2016).

Taubenberger JK, M. D. (2009). pandemic influenza: including a risk assessment of H5NI. 28, 187-202.

Veen, R. C. T. (2008). Charitable Giving in Islam, United Kingdom: Islamic Relief Worldwide.

wang, Z., Qiang, W., Ke, H. (2020). A handbook of 2019-nCoV pneumonia conntrol and prevention. china: Hubei science and technologi press.

WHO, W. H. O. (2020). Novel Corona Virus Qualiti Assurance for Public Helalth.

Widiyon, S. S. and. (2013). Research Methodology for Thesis and Thesis Writing. Jakarta: IN Media.

Widodo, A. S., Dimyati, A., \& Dhiani, H. P. (2020). Social Responsibility Application: Social Service Activities During the COVID-19 Pandemic In Kukusan Village Rt 06 Rw 05 Beji District, Depok, West Java 16425. $1(3), 33-40$.

Yulianan, what's going on? (2020). Corona Virus Diseases (Covid-19): A Literature Review. 